\title{
International Journal of Polymer Analysis and Characterization
}

ISSN: 1023-666X (Print) 1563-5341 (Online) Journal homepage: http://www.tandfonline.com/loi/gpac20

\section{Metal chloride-catalyzed acetylation of starch: Synthesis and characterization}

\section{Atanu Biswas, Sanghoon Kim, Roselayne Ferro Furtado, Carlucio Roberto} Alves, Megan Buttrum, Veera Boddu \& H. N. Cheng

To cite this article: Atanu Biswas, Sanghoon Kim, Roselayne Ferro Furtado, Carlucio Roberto Alves, Megan Buttrum, Veera Boddu \& H. N. Cheng (2018) Metal chloride-catalyzed acetylation of starch: Synthesis and characterization, International Journal of Polymer Analysis and Characterization, 23:6, 577-589, DOI: 10.1080/1023666X.2018.1512465

To link to this article: https://doi.org/10.1080/1023666X.2018.1512465

册 Published online: 17 Sep 2018.

Submit your article to this journal $[\pi$

Џ Article views: 20

View Crossmark data ¿ 


\title{
Metal chloride-catalyzed acetylation of starch: Synthesis and characterization
}

\author{
Atanu Biswas ${ }^{\mathrm{a}}$ (D), Sanghoon Kim ${ }^{\mathrm{a}}$, Roselayne Ferro Furtado ${ }^{\mathrm{b}}$, Carlucio Roberto Alves ${ }^{\mathrm{c}}$, \\ Megan Buttrum ${ }^{a}$, Veera Boddu ${ }^{a}$, and H. N. Cheng ${ }^{d}$ (ID \\ aUSDA Agricultural Research Service, National Center for Agricultural Utilization Research, Peoria, IL, USA; \\ ${ }^{b}$ Embrapa Agroindústria Tropical, Dra. Sara Mesquita, Fortaleza, Ceará, Brazil; 'State University of Ceará, \\ Fortaleza, CE, Brazil; ${ }^{d}$ USDA Agricultural Research Service, Southern Regional Research Center, New Orleans, \\ LA, USA
}

\begin{abstract}
Acylation of polysaccharides is a commercially important reaction and is usually performed in a process involving the polysaccharide, an acid anhydride, and an inorganic acid. As an alternative to inorganic acid, many catalysts, including some metal chlorides, have been previously reported as catalysts. In this work, we took a more comprehensive look at several metal chlorides to observe trends and reactivities among them, particularly relating to reaction temperature, time, and amount of acetic anhydride used. lodine was also included for comparison. Almost all the metal chlorides studied were found to be active as catalysts for the acetylation of starch under suitable reaction conditions. However, each metal chloride had a somewhat different reactivity with a different optimal temperature needed for satisfactory reactions to take place. The molecular weight of the starch acetate products decreased in all cases observed. The reactivity trends among the metal halides seemed to correlate both with the ease of complexation between the halide and the substrate and with the acidity of the metal chloride. Characterization was achieved through ${ }^{13} \mathrm{C}$ NMR, FT$\mathrm{IR}$, thermogravimetric analysis and size exclusion chromatography.
\end{abstract}

\section{ARTICLE HISTORY}

Received 26 July 2018

Accepted 10 August 2018

\section{KEYWORDS}

Acetylation; esterification; Lewis acids; metal

chlorides; starch

\section{Introduction}

Acylation of polysaccharide is an important chemical reaction that has significant commercial impact. For example, cellulose acetate ${ }^{[1,2]}$ and other cellulose esters are used extensively in many applications, such as apparel, home furnishings, glass frames, cigarette filters, coatings, and films. Starch acetate ${ }^{[3-5]}$ is also well known and used as food additive, textile sizing, adhesive, and ingredient for grease-proofing paper. Several reviews ${ }^{[6-9]}$ and at least one book ${ }^{[10]}$ have been written about esterification of polysaccharides.

Many of the synthetic methods employed for acylation were developed for low-molecularweight carbohydrates or related alcohols; some of them were then adapted for polysaccharides. For convenience, these methods can be grouped into several categories. A major category is the use of a strong acid in combination with an anhydride. An example is the commercial process for the acetylation of cellulose, which is conducted in the presence of acetic anhydride, acetic acid, and sulfuric acid ${ }^{[10-11]}$. Instead of sulfuric acid, perchloric acid ${ }^{[12-13]}$, trifluoroacetic 
acid $^{[14]}$, methanesulfonic acid ${ }^{[15]}$, scandium trifluoromethanesulfonates ${ }^{[16,17]}$, and cupric trifluoromethanesulfonates ${ }^{[18]}$ have been utilized as a catalyst for the reaction. The second category includes the Lewis acid catalysts, and several have been used, for example, indium chloride $^{[19]}$, cobalt chloride ${ }^{[20]}$, zinc chloride ${ }^{[15]}$, ferric chloride ${ }^{[21]}$, and bismuth chloride ${ }^{[22]}$ in combination with acetic anhydride. Iodine has been reported as an acylation catalyst for sug$\operatorname{ars}^{[23]}$, and this has been extensively utilized by us ${ }^{[24]}$ and several others for polysaccharides $^{[25-27]}$.

A different category of catalysts consists of basic compounds. In fact, most commercial starch esters are prepared by aqueous suspension reaction of starch, anhydride, and sodium hydroxide maintained at $\mathrm{pH} 7-9^{[17,28,29]}$. Similar reactions involving starch, anhydride, and sodium hydroxide were used in many recent publications on starch acetylation ${ }^{[30-35]}$. Other basic compounds used include pyridine and N,N-dimethylaminopyridine ${ }^{[36]}$, imidazole ${ }^{[37]}$, ammonium halide ${ }^{[38]}$, and potassium carbonate ${ }^{[39]}$. Ionic liquids containing methyl imidazolium functionality ${ }^{[40-42]}$ have also been reported in connection with acetylation, and they can perhaps be grouped with basic compounds.

Yet another category of catalysts comprises the heterogeneous catalysts, including montmorillonite $\mathrm{K}-10^{[43]}$, zeolites ${ }^{[44]}$, Nafion- $\mathrm{H}^{[45]}$, and $\mathrm{Al}_{2} \mathrm{O}_{3}{ }^{[46]}$. A different category comprises enzymes (particularly lipases), which have been reported for the esterification of some polysaccharides ${ }^{[8]}$. There are also the multicomponent catalysts, involving more than one type of materials from two catalyst categories, such as perchloric acid- $\mathrm{SiO}_{2}{ }^{[47]}$ and choline chloride/zinc chloride ion liquid ${ }^{[48]}$. A final method that may be mentioned entails the carbonation of cellulose with $\mathrm{CO}_{2}$ in the presence of strong organic bases, leading to the dissolution of cellulose in DMSO and acetylation with acetic anhydride without external catalysts ${ }^{[49]}$. For starch acetylation, many of the synthetic methods have been recently reviewed ${ }^{[3]}$.

As we surveyed the literature, the metal chlorides thus far have been studied individually as Lewis acid catalysts for acetylation of polysaccharides. The objective of this work was to take a more comprehensive look at an expanded list of metal chlorides and compare their catalytic effects on the acetylation of starch, particularly regarding reaction temperature, time, and amount of acetic anhydride used. These are the parameters that are most related to reaction efficiency and economy. Iodine was included in the study as a reference. As it turned out, all metal chlorides studied showed varying degrees of catalytic activity; however, the reaction conditions (particularly temperature) needed to be customized for each metal chloride to optimize the outcome. These data and analyses should be useful in the design of future processes using Lewis acids to catalyze the acetylation of polysaccharides.

\section{Materials and methods}

\section{Materials}

The sample of wheat starch was purchased from Sigma Aldrich (St. Louis, MO, USA). Iodine, aluminum chloride, ferric chloride, hydrated ferric chloride, zinc chloride, antimony chloride, tin chloride, cupric chloride, and hydrated nickel chloride also came from Sigma Aldrich. Acetic anhydride, sodium bicarbonate, methylene chloride, hydrated tin chloride, and hydrated cobalt chloride were acquired from Fisher Scientific (Pittsburgh, PA, USA). Cobalt chloride and nickel chloride were purchased from Acros Organics through Fisher Scientific. Absolute ethanol came from Decon Laboratories, Inc. (King of Prussia, PA, USA). Dimethylsulfoxide- $\mathrm{d}_{6}$ $\left(\mathrm{d}_{6}\right.$-DMSO) was obtained from Cambridge Isotope Laboratories (Andover, MA, USA). For convenience, all metal chlorides mentioned in the text were anhydrous, unless specifically noted as hydrated. 


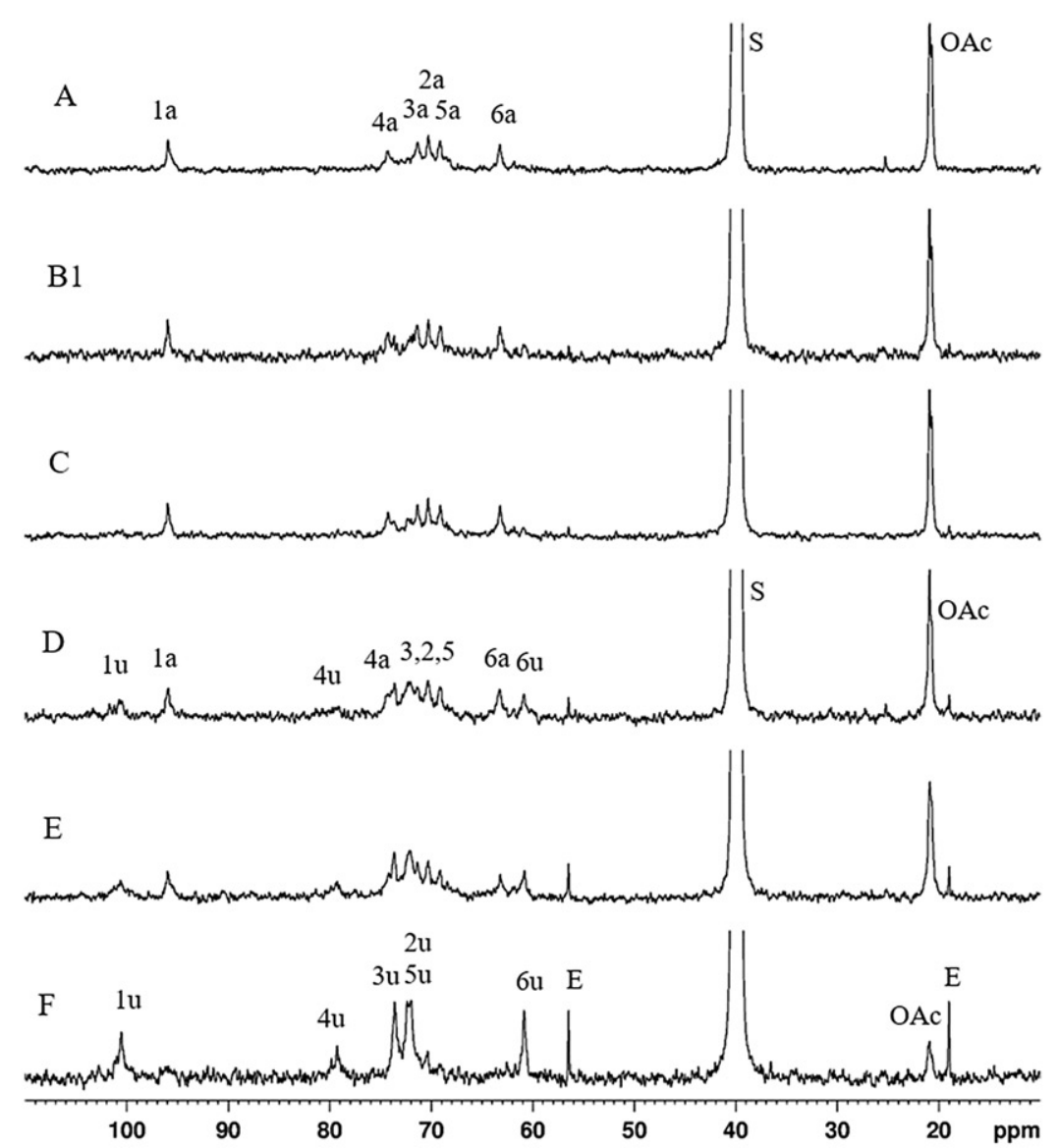

Figure 1. ${ }^{13} \mathrm{C}$ NMR spectra (at 10-110 ppm) of acetylated starch samples A, B1, C, D, E, and F, as described in Table 4. Arabic numerals refer to carbon numbers, where $u$ and a denote unreacted and acetylated carbons on starch, respectively; $S=d_{6}-D M S O$, and $\mathrm{E}=$ ethanol.

\section{Synthetic procedure}

The procedure was adapted from the iodine-catalyzed acetylation reaction of Biswas et al. ${ }^{[24]}$. In a typical reaction, $0.5 \mathrm{~g}$ of starch, $0.2-2.5 \mathrm{~mL}$ of acetic anhydride, and $0.05 \mathrm{~g}$ of a catalyst were heated at $50-110^{\circ} \mathrm{C}$ for $6-24 \mathrm{~h}$; no solvent was used. The reaction mixture was then cooled to room temperature and neutralized with an aqueous solution of sodium bicarbonate while stirring. The mixture was poured into $10 \mathrm{~mL}$ of ethanol and stirred for $30 \mathrm{~min}$. The solid, which contained starch acetate, was filtered and washed with water/ethanol and dried in a vacuum oven at $60^{\circ} \mathrm{C}$. Under the reaction conditions, the yields were all $>90 \%$.

\section{Analysis and characterization}

NMR spectra were obtained on a DRX400 spectrometer from Bruker Instruments (Carlstadt, Germany). Standard instrumental conditions were used for ${ }^{1} \mathrm{H}$ and ${ }^{13} \mathrm{C}$ NMR with $\mathrm{d}_{6}$-dimethylsulfoxide (DMSO) as the solvent. All chemical shifts were referenced to tetramethylsilane at $0 \mathrm{ppm}$. The degree of substitution (DS) was calculated from the spectral areas obtained from the ${ }^{13} \mathrm{C}$ NMR spectra (Figure 1). This can be conducted by taking the total area (A2) of starch peaks at $60-110 \mathrm{ppm}$. If the area of the acetate methyl peak at $21 \mathrm{ppm}$ is $\mathrm{A} 1$, the DS is then $\mathrm{A} 1^{*} 6 / \mathrm{A} 2$. 
Table 1. Effect of reaction temperature on the degree of substitution (DS) for acetylation of starch using Lewis acid catalysts. All reactions were conducted on $0.5 \mathrm{~g}$ starch, $1 \mathrm{~mL} \mathrm{Ac} 20,0.05 \mathrm{~g}$ catalyst, and with 6-hour reaction time.

\begin{tabular}{|c|c|c|c|c|c|c|c|}
\hline \multirow[b]{2}{*}{ Catalyst } & \multicolumn{7}{|c|}{ DS at the indicated temperature } \\
\hline & $110^{\circ} \mathrm{C}$ & $100^{\circ} \mathrm{C}$ & $80^{\circ} \mathrm{C}$ & $70^{\circ} \mathrm{C}$ & $60^{\circ} \mathrm{C}$ & $50^{\circ} \mathrm{C}$ & $40^{\circ} \mathrm{C}$ \\
\hline $\mathrm{FeCl}_{3}$ & & $0^{*}$ & $0.3^{*}$ & & 2.5 & 1.6 & 0.7 \\
\hline $\mathrm{ZnCl}_{2}$ & & 2.7 & 1.8 & & 0.2 & & \\
\hline $\mathrm{AlCl}_{3}$ & & 3.1 & 3.1 & 1.4 & 0.6 & & \\
\hline $\mathrm{SbCl}_{3}$ & & 3.1 & 1.1 & & 0.3 & & \\
\hline $\mathrm{SnCl}_{2}$ & & 3.1 & 2.6 & 1.2 & 0.8 & & \\
\hline $\mathrm{I}_{2}$ & & $3.0^{*}$ & 2.9 & & 2.2 & 1.5 & 0.6 \\
\hline $\mathrm{CuCl}_{2}$ & 3.1 & 2.7 & 0.2 & & 0.0 & & \\
\hline $\mathrm{CoCl}_{2}$ & & 1.9 & 0.4 & & 0.1 & & \\
\hline $\mathrm{NiCl}_{2}$ & & 0.3 & 0.1 & & 0.0 & & \\
\hline
\end{tabular}

*Sample charred. Results obtained only from dissolved part of sample.

At higher reaction temperatures sometimes charring was observed on a few samples; in those cases only the DMSO-soluble part of a product was analyzed by NMR.

FTIR spectra were acquired on a Nicolet iS10 spectrometer (Thermo Scientific Inc., Waltham, MA, USA) equipped with a Smart Orbit single bounce ATR accessory with a diamond crystal. The scanning range was $500-4000 \mathrm{~cm}^{-1}$ with a spectral resolution of $4 \mathrm{~cm}^{-1}$. Each spectrum was the average of 32 scans. The software used was Omnic 9 (version 9.2.98), which automatically removed the baseline drifts from the spectra.

Thermogravimetric analysis (TGA) was performed on a TA Instruments Q500 TGA (New Castle, DE, USA) with nitrogen purge. Each sample (about $10 \mathrm{mg}$ ) was loaded in an open platinum pan and heated in nitrogen from room temperature to $600^{\circ} \mathrm{C}$ at $10^{\circ} \mathrm{C} / \mathrm{min}$.

Size-exclusion chromatography (SEC) was performed using a Shimadzu Prominence LC system (Shimadzu, Kyoto, Japan) equipped with refractive index (RI) and diode-array (UV) detectors. DMSO was used as the mobile phase as well as solvent for the samples. A $0.5 \%$ solution of each sample was prepared in DMSO. The sample was filtered using a $0.45-\mu \mathrm{m}$ syringe filter, then $50 \mu \mathrm{L}$ of sample was injected on the SEC at a flow rate of $0.5 \mathrm{~mL} / \mathrm{min}$ using a Phenogel $5 \mu$ Linear(2) SEC column (Phenomenex, Torrance, CA, USA) at $60^{\circ} \mathrm{C}$. Dextran standards were used for molecular weight calibration.

\section{Results}

In our effort to generalize the catalysis of acylation of polysaccharides with metal chlorides, we chose, as proof of principle, the acetylation of starch with eight metal chlorides: iron (III) chloride, zinc(II) chloride, aluminum(III) chloride, antimony(III) chloride, tin(II) chloride, copper(II) chloride, cobalt(II) chloride, and nickel(II) chloride. Iodine-based catalysis was used as a reference. The reaction variables studied included reaction temperature, reaction time, and level of acetic anhydride used. Furthermore, a comparison was made of the reactions conducted with several anhydrous versus hydrated metal chlorides.

The effect of temperature on the degree of substitution of acetate on starch is summarized in Table 1. With the exception of $\mathrm{FeCl}_{3}$, a higher reaction temperature led to a higher degree of substitution for the catalysts studied. However, at the highest temperatures, sometimes the DS exceeded 3.0, indicating the presence of chain degradation and the acetylation of chain ends. The profile of DS versus temperature showed a lot of variations, depending on the metal chloride involved. To get DS values between 1.5 and 3.0, the optimal temperature seemed to be around $80^{\circ} \mathrm{C}$ for $\mathrm{ZnCl}_{2}, \mathrm{AlCl}_{3}, \mathrm{SbCl}_{3}$, and $\mathrm{SnCl}_{2}$. In contrast, $\mathrm{NiCl}_{2}$ and $\mathrm{CoCl}_{2}$ were less reactive; even at $100^{\circ} \mathrm{C}$, the $\mathrm{DS}$ value for $\mathrm{CoCl}_{2}$ was $1.9 . \mathrm{CuCl}_{2}$ showed the greatest temperature sensitivity; at $100^{\circ} \mathrm{C}$ the DS was almost 3.0 , but at $80^{\circ} \mathrm{C}$, it was 0.2 . 
Table 2. Effect of reaction time and $\mathrm{Ac}_{2} \mathrm{O}$ level on the degree of substitution (DS) of starch acetate. All reactions were conducted on $0.5 \mathrm{~g}$ starch and $0.05 \mathrm{~g}$ catalyst.

\begin{tabular}{lcccc}
\hline Catalyst & $\mathrm{Ac}_{2} \mathrm{O}(\mathrm{mL})$ & $\mathrm{T}\left({ }^{\circ} \mathrm{C}\right)$ & $\mathrm{t}(\mathrm{h})$ & $\mathrm{DS}$ \\
\hline $\mathrm{FeCl}_{3}$ & 1 & 80 & 6 & $0.3^{*}$ \\
& 2.5 & 80 & 6 & $2.4^{*}$ \\
& 0.5 & 80 & 6 & $0.2^{*}$ \\
& 1 & 80 & 24 & $0.1^{*}$ \\
& 1 & 60 & 24 & 2.8 \\
$\mathrm{AlCl}_{3}$ & 1 & 60 & 6 & 2.5 \\
& 1 & 80 & 6 & 3.1 \\
& 0.5 & 80 & 6 & 1.4 \\
& 0.2 & 80 & 6 & 0.4 \\
$\mathrm{SnCl}_{2}$ & 1 & 60 & 24 & 2.0 \\
& 1 & 60 & 6 & 0.6 \\
& 1 & 80 & 6 & 2.6 \\
& 0.5 & 80 & 6 & 0.6 \\
& 0.2 & 80 & 6 & 0.2 \\
& 1 & 60 & 24 & 0.8 \\
\end{tabular}

*Sample charred. Results obtained only from dissolved part of sample.

$\mathrm{FeCl}_{3}$ showed a very different temperature behavior from the other metal halides. At $80{ }^{\circ} \mathrm{C}$ and $100{ }^{\circ} \mathrm{C}, \mathrm{FeCl}_{3}$ appeared to be very reactive such that extensive polymer degradation and hydrolysis occurred (as shown by sample charring), and not much usable product was recovered. Because of its high reactivity, lower reaction temperatures were attempted for $\mathrm{FeCl}_{3}$. The optimal temperature for DS between 1.5 and 3.0 for $\mathrm{FeCl}_{3}$ was around $50-60{ }^{\circ} \mathrm{C}$. In comparison, iodine was also shown to be rather reactive; the optimal temperature for DS $1.5-3.0$ was about $50-80{ }^{\circ} \mathrm{C}$.

The effects of reaction time, level of acetic anhydride, and reaction temperature for three metal chlorides $-\mathrm{FeCl}_{3}, \mathrm{AlCl}_{3}$, and $\mathrm{SnCl}_{2}$ - are shown in Table 2. These data confirmed the high activity of $\mathrm{FeCl}_{3}$ as a catalyst. At $80^{\circ} \mathrm{C}$ reaction temperature, all the $\mathrm{FeCl}_{3}$-catalyzed samples charred to varying degrees. However, at $60^{\circ} \mathrm{C}$ almost complete acetylation was achieved without sample charring. For $\mathrm{AlCl}_{3}$ and $\mathrm{SnCl}_{2}, 80^{\circ} \mathrm{C}$ seemed to be the optimal temperature at $\mathrm{Ac}_{2} \mathrm{O}$ level of $1 \mathrm{~g}$ to achieve a high DS. From data shown in Table 2, a longer reaction time generally gives a higher DS value. Likewise, a higher acetic anhydride level also produces a higher DS value. In a given process, if a lower DS is desired, then a lower reaction temperature, a shorter reaction time, and a reduced anhydride level can be used.

Many of the metal chlorides can be available in both anhydrous and hydrated forms. One may be curious to find out if the acetylation reaction changes when anhydrous versus hydrated metal chlorides are used. The side-by-side comparison of four anhydrous and hydrated metal chlorides $\left(\mathrm{FeCl}_{3}, \mathrm{SnCl}_{2}, \mathrm{CoCl}_{2}\right.$, and $\left.\mathrm{NiCl}_{2}\right)$ showed, perhaps surprisingly, that there was no significant difference in the DS with the water of hydration for the metal chlorides (Table 3). Thus, either anhydrous and or hydrated chlorides can be used for starch acetylation.

The ${ }^{13} \mathrm{C}$ NMR spectra of a few selected starch acetate samples (Table 4) are shown in Figure 1. Spectral assignments can be made from those reported in the literature ${ }^{[50-51]}$ and from chemical shift additivity rules ${ }^{[52]}$. Thus, the (unreacted) starch peaks are found at $100.6 \mathrm{ppm}(\mathrm{C} 1)$, $79.3 \mathrm{ppm}(\mathrm{C} 4), 73.6 \mathrm{ppm}(\mathrm{C} 3), 72.0 \mathrm{ppm}$ (C3 and C5), and $60.9 \mathrm{ppm}(\mathrm{C} 6)^{[53]}$. The fully acetylated starch peaks occur at $96.0 \mathrm{ppm}(\mathrm{C} 1), 74.3 \mathrm{ppm}(\mathrm{C} 4), 71.4 \mathrm{ppm}(\mathrm{C} 3), 70.3 \mathrm{ppm}(\mathrm{C} 2), 69.1 \mathrm{ppm}$ (C5), and $63.2 \mathrm{ppm}$ (C6). These peak assignments are noted in Figure 1, where the DS decreases in general from sample A to $\mathrm{F}$ (Table 4). For samples D and $\mathrm{E}$ the peaks for both unreacted and reacted starch can be seen in the same spectra.

The FT-IR spectra of starch and three samples of $\mathrm{SnCl}_{2}$-catalyzed acetylated starch (Table 4) with increasing acetylation are shown in Figure 2. The spectrum of starch is well known with characteristic bands for C-O, C-C and C-O-H stretching and $\mathrm{C}-\mathrm{O}-\mathrm{H}$ bending at around 1000$1200 \mathrm{~cm}^{-1}, \mathrm{C}-\mathrm{H}$ bands at $2910 \mathrm{~cm}^{-1}$, and broad $\mathrm{O}-\mathrm{H}$ bands at $3400 \mathrm{~cm}^{-1[54,55]}$. After acetylation, 
Table 3. Effect of metal chloride water of hydration on the degree of substitution (DS) of starch acetate. All reactions were conducted on $0.5 \mathrm{~g}$ starch, $1 \mathrm{~mL} \mathrm{Ac_{2 }} \mathrm{O}, 0.05 \mathrm{~g}$ catalyst, and with 6-hour reaction time.

\begin{tabular}{|c|c|c|c|c|c|}
\hline \multirow[b]{2}{*}{ Catalyst } & \multicolumn{5}{|c|}{ DS at the indicated temperature } \\
\hline & $100^{\circ} \mathrm{C}$ & $80^{\circ} \mathrm{C}$ & $70^{\circ} \mathrm{C}$ & $60^{\circ} \mathrm{C}$ & $50^{\circ} \mathrm{C}$ \\
\hline anhydrous $\mathrm{FeCl}_{3}$ & & $0.3^{*}$ & & 2.5 & 1.6 \\
\hline $\mathrm{FeCl}_{3}$ hydrate & & 0.7 & & 2.4 & 1.5 \\
\hline anhydrous $\mathrm{SnCl}_{2}$ & & 2.6 & 1.2 & 0.8 & \\
\hline $\mathrm{SnCl}_{2}$ hydrate & & 2.5 & 1.4 & 0.8 & \\
\hline anhydrous $\mathrm{CoCl}_{2}$ & 1.7 & 0.4 & & 0.1 & \\
\hline $\mathrm{CoCl}_{2}$ hydrate & 1.7 & 0.3 & & 0.1 & \\
\hline anhydrous $\mathrm{NiCl}_{2}$ & 0.3 & 0.1 & & 0.0 & \\
\hline $\mathrm{NiCl}_{2}$ hydrate & 0.5 & 0.2 & & 0.1 & \\
\hline
\end{tabular}

*Sample charred. Results obtained only from dissolved part of sample.

Table 4. Information on samples for ${ }^{13} \mathrm{C}$ NMR, FT-IR, and TGA. All reactions were conducted on $0.5 \mathrm{~g}$ starch, $0.05 \mathrm{~g}$ catalyst, and with 6-hour reaction time.

\begin{tabular}{llcrr}
\hline No. & Catalyst & $\mathrm{Ac}_{2} \mathrm{O}(\mathrm{mL})$ & $\mathrm{T}(\mathrm{C})$ & $\mathrm{DS}$ \\
\hline A & $\mathrm{AlCl}_{3}$ & 1 & 80 & 3.5 \\
B1 & $\mathrm{SnCl}_{2}$ & 1 & 80 & 3.8 \\
B2 & $\mathrm{SnCl}_{2}$ & 0.5 & 80 & 1.0 \\
B3 & $\mathrm{SnCl}_{2}$ & 0.2 & 80 & 0.2 \\
C & $\mathrm{CuCl}_{2}$ & 1 & 100 & 3.0 \\
D & $\mathrm{SbCl}_{3}$ & 1 & 100 & 2.1 \\
E & $\mathrm{CoCl}_{2}$ & 1 & 100 & 1.7 \\
F & $\mathrm{NiCl}_{2}$ & 1 & 0.5 \\
\hline
\end{tabular}

new bands showed up at $1750,1440,1380$, and $1230 \mathrm{~cm}^{-1}$, due to carbonyl $\mathrm{C}=\mathrm{O}, \mathrm{CH}_{3}$ antisymmetric deformation vibration, $\mathrm{CH}_{3}$ symmetric deformation vibration, and carbonyl $\mathrm{C}-\mathrm{O}$ stretch vibrations, respectively, in agreement with the literature ${ }^{[56,57]}$. With increasing DS, the bands due to acetylation increased in intensity, but the broad $\mathrm{O}-\mathrm{H}$ band at $3400 \mathrm{~cm}^{-1}$ decreased in intensity such that at DS 3.0, it completely disappeared, indicating the absence of $\mathrm{OH}$ groups.

The same four $\mathrm{SnCl}_{2}$-catalyzed samples were subjected to TGA analysis (Figure 3). It seems that weight loss for these samples depends on two main factors: 1) degree of acetylation, where increasing acetylation enhances thermal stability, and 2) molecular weight degradation, which makes the polymer thermally less stable. Thus, the unmodified starch showed a peak maximum in the DTG curve at around $300^{\circ} \mathrm{C}$. With the addition of $\mathrm{SnCl}_{2}$ and $0.2 \mathrm{~g}$ acetic anhydride (sample B3), the DS was only 0.2 , but the molecular weight also degraded, so that the peak maximum in the DTG curve decreased significantly to $230^{\circ} \mathrm{C}$. With increasing acetic anhydride, the DS increased to 0.6 (for sample B2) and 2.6 (for sample B1); the peak maxima for DTG curves also increased to $230-310^{\circ} \mathrm{C}$ (two peaks) and $330^{\circ} \mathrm{C}$, respectively.

A study of the molecular weight distribution of the acetylated starch samples indicated that with the use of metal chlorides and iodine, all samples showed varying degrees of molecular weight degradation. This confirmed what was reported earlier for iodine ${ }^{[24,58]}$. For starch acetate obtained with the reaction of $0.5 \mathrm{~g}$ starch, $1 \mathrm{~mL}$ acetic anhydride, and $0.05 \mathrm{~g}$ catalyst at $80^{\circ} \mathrm{C}$ for $6 \mathrm{~h}$, the number-average $\left(\mathrm{M}_{\mathrm{n}}\right)$, and weight average $\left(\mathrm{M}_{\mathrm{w}}\right)$ molecular weights are given in Table 5 . The molecular weight distributions are shown as size exclusion chromatograms in Figure 4, and the distributions are all very broad. The starting wheat starch has a $\mathrm{M}_{\mathrm{w}}$ of $1532 \mathrm{kDa}$. The use of iodine for acetylation appears to be most deleterious for the molecular weight of acetylated starch; the $\mathrm{M}_{\mathrm{w}}$ drops to $4.4 \mathrm{kDa}$. Among metal chlorides, $\mathrm{AlCl}_{3}$ and $\mathrm{FeCl}_{3}$ show the most reduction in the molecular weight of acetylated starch (with $\mathrm{M}_{\mathrm{w}}$ about $26-31 \mathrm{kDa}$ ). Three metal chlorides show the least reduction: $\mathrm{SbCl}_{3}, \mathrm{ZnCl}_{2}$, and $\mathrm{SnCl}_{2}$ (with $\mathrm{M}_{\mathrm{w}}$ in the range of $179-207 \mathrm{kDa}$ ), and three metal chlorides are in the middle: $\mathrm{CoCl}_{2}, \mathrm{CuCl}_{2}$, and $\mathrm{NiCl}_{2}\left(\mathrm{M}_{\mathrm{w}}\right.$ about $\left.40-72 \mathrm{kDa}\right)$. Thus, if we prefer to minimize molecular weight degradation of starch during acetylation at $80^{\circ} \mathrm{C}, \mathrm{SnCl}_{2}, \mathrm{ZnCl}_{2}$, or $\mathrm{SbCl}_{2}$ can be selected as the catalyst. 


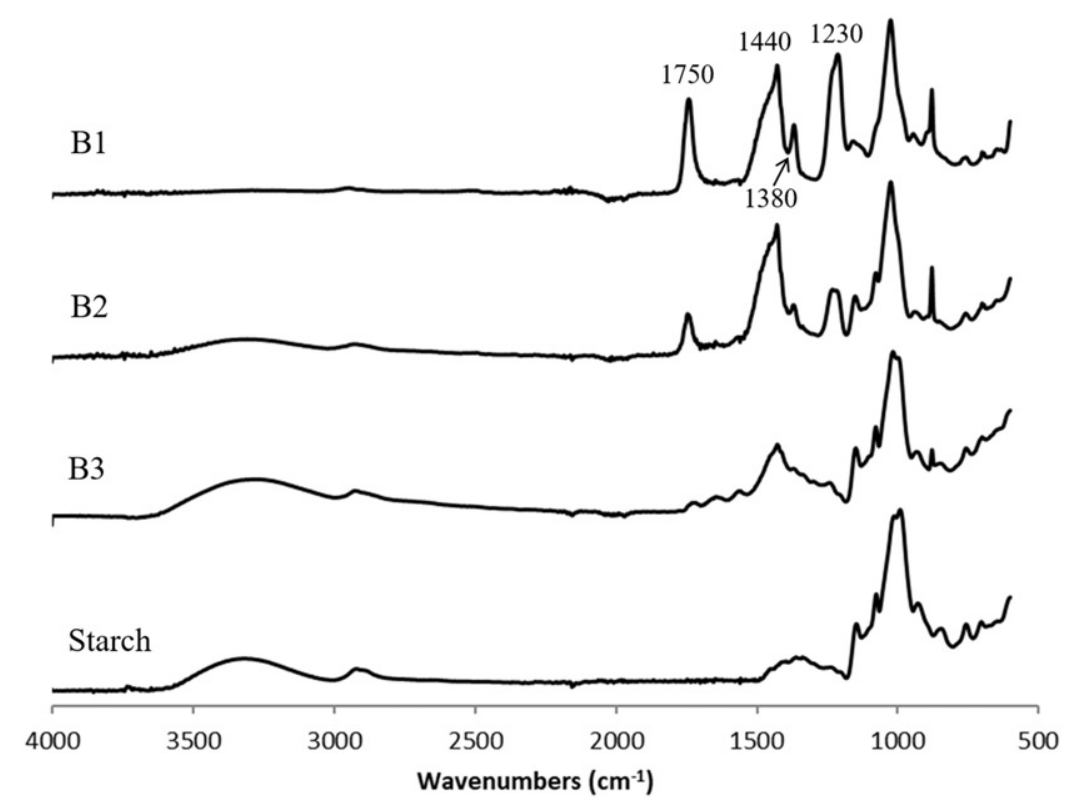

Figure 2. FT-IR spectra of acetylated starch samples, B1, B2, and B3, as described in Table 4, and unmodified starch.

\section{Discussion}

Results shown above indicate that all metal chlorides studied herein can be used as catalysts for starch acetylation. However, the reaction conditions (particularly temperature) need to be optimized to produce desired results. The level of acetic anhydride and the reaction time are the secondary factors that also affect the DS.

Although all metal chlorides are capable of acetylating starch, they have different reactivities. At $100{ }^{\circ} \mathrm{C}$ reaction temperature, the relative reactivity of the catalysts (and the DS) at $1 \mathrm{~g} \mathrm{Ac}_{2} \mathrm{O}$ and reaction time of $6 \mathrm{~h}$ are shown below. $\mathrm{FeCl}_{3}$ is excluded from this trend as the products charred due to the overactivity of that catalyst.

$\mathrm{SnCl}_{2}(3.1), \mathrm{SbCl}_{3}(3.1), \mathrm{CuCl}_{2}(3.1), \mathrm{AlCl}_{3}(3.1), \mathrm{I}_{2}(3.0), \mathrm{ZnCl}_{2}(2.7), \mathrm{CoCl}_{2}(1.9), \mathrm{NiCl}_{2}(0.3)$

At $80^{\circ} \mathrm{C}$, the DS of starch obtained using $1 \mathrm{~g} \mathrm{Ac} 2 \mathrm{O}$ and $6 \mathrm{~h}$ of reaction time follows the decreasing trend. Again, $\mathrm{FeCl}_{3}$ is excluded due to char formation.

$\mathrm{AlCl}_{3}(3.1), \mathrm{I}_{2}(2.9), \mathrm{SnCl}_{2}(2.6), \mathrm{ZnCl}_{2}(1.8), \mathrm{SbCl}_{3}(1.1), \mathrm{CoCl}_{2}(0.4), \mathrm{CuCl}_{2}(0.2), \mathrm{NiCl}_{2}(0.1)$

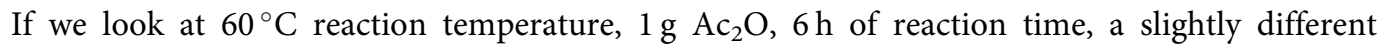
decreasing DS trend is obtained:

$\mathrm{FeCl}_{3}(2.5), \mathrm{I}_{2}(2.2), \mathrm{SnCl}_{2}(0.8), \mathrm{AlCl}_{3}(0.6), \mathrm{SbCl}_{3}(0.3), \mathrm{ZnCl}_{2}(0.2), \mathrm{CoCl}_{2}(0.1), \mathrm{CuCl}_{2}(0), \mathrm{NiCl}_{2}(0)$

The above trends at the three temperatures are not quite the same but show some similarities. The strongest catalysts seem to be $\mathrm{FeCl}_{3}, \mathrm{AlCl}_{3}, \mathrm{I}_{2}$, and $\mathrm{SnCl}_{2}$; the weakest catalysts are $\mathrm{CoCl}_{2}$ and $\mathrm{NiCl}_{2}$. However, each individual catalyst behaves differently. In particular, $\mathrm{FeCl}_{3}$ is highly active and is best used for acetylation at lower temperatures $\left(60-70^{\circ} \mathrm{C}\right)$, whereas acetylation with iodine is better conducted at about $80^{\circ} \mathrm{C}$.

It may be noted that although the functions of Lewis acids in chemical reactions are wellknown, there appears to be no universal Lewis acidity scale. The reactivity of different Lewis acids appears to depend on the reactions and the mechanisms involved. The Guttman-Beckett method 

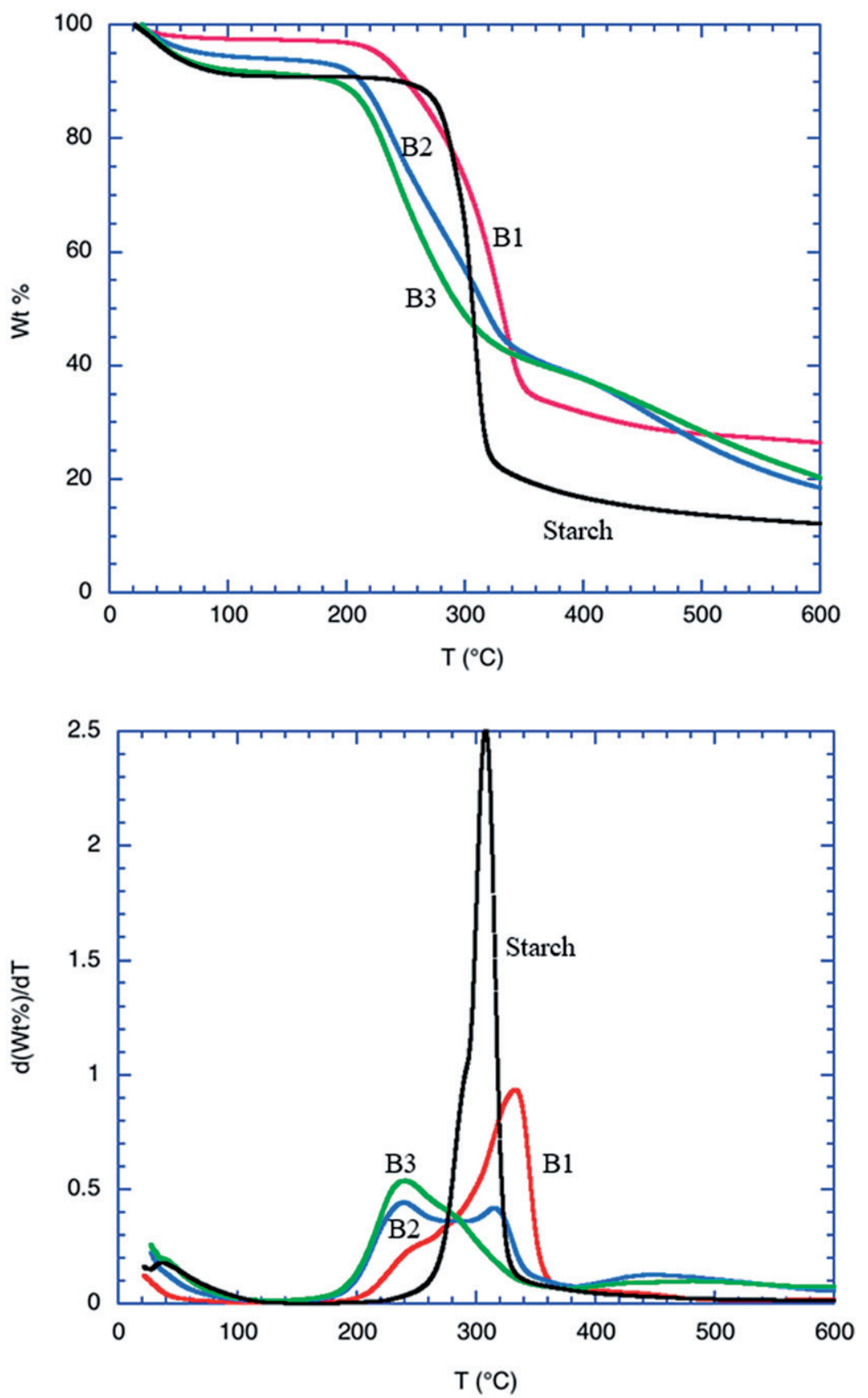

Figure 3. Thermogravimetric analysis (TGA, top) and differential thermogravimetric (DTG, bottom) curves for $\mathrm{SnCl}_{2}$-catalyzed acetylation of starch. The samples were described in Table 4 and depicted in black (wheat starch sample), green (sample B3), blue (sample B2), and red (sample B1).

was based on ${ }^{31} \mathrm{P}$ NMR chemical shifts for boron-containing Lewis acids and is well known as a procedure to assess the Lewis acidity of molecular species ${ }^{[59,60]}$. Another extensive Lewis acid classification by Olah et al was based on Friedel-Crafts reaction ${ }^{[61]}$. Kobayashi et al ${ }^{[62]}$ proposed a kinetic and reactivity classification based on a large range of Lewis acids. Many other notable contributions to Lewis acid scales have also been made by several research groups over the years ${ }^{[63-68]}$. 
Table 5. Molecular weights (in $\mathrm{kDa}$ ) of metal chloride- and iodine-catalyzed acetylated (Ac) starch; reaction conditions entailed $0.5 \mathrm{~g}$ starch, $1 \mathrm{~mL}$ acetic anhydride, $0.05 \mathrm{~g}$ catalyst, $80^{\circ} \mathrm{C}$ reaction temperature, and 6-hour reaction time.

\begin{tabular}{lccc}
\hline Sample & $\mathrm{M}_{\mathrm{w}}$ & $\mathrm{M}_{\mathrm{n}}$ & $\mathrm{M}_{\mathrm{w}} / \mathrm{M}_{\mathrm{n}}$ \\
\hline Ac Starch - I & 4.4 & 0.9 & 5 \\
Ac Starch - AlCl & 26 & 2 & 12 \\
Ac Starch - $\mathrm{FeCl}_{3}$ & 31 & 3 & 11 \\
Ac Starch - $\mathrm{CoCl}_{2}$ & 40 & 3 & 13 \\
Ac Starch - $\mathrm{CuCl}_{2}$ & 58 & 3 & 18 \\
Ac Starch - $\mathrm{NiCl}_{2}$ & 72 & 3 & 28 \\
Ac Starch - SbCl & 179 & 11 & 17 \\
Ac Starch - $\mathrm{ZnCl}_{2}$ & 193 & 5 & 40 \\
Ac Starch - SnCl & 207 & 6 & 36 \\
Unreacted Starch & 1532 & 197 & 8 \\
\hline
\end{tabular}

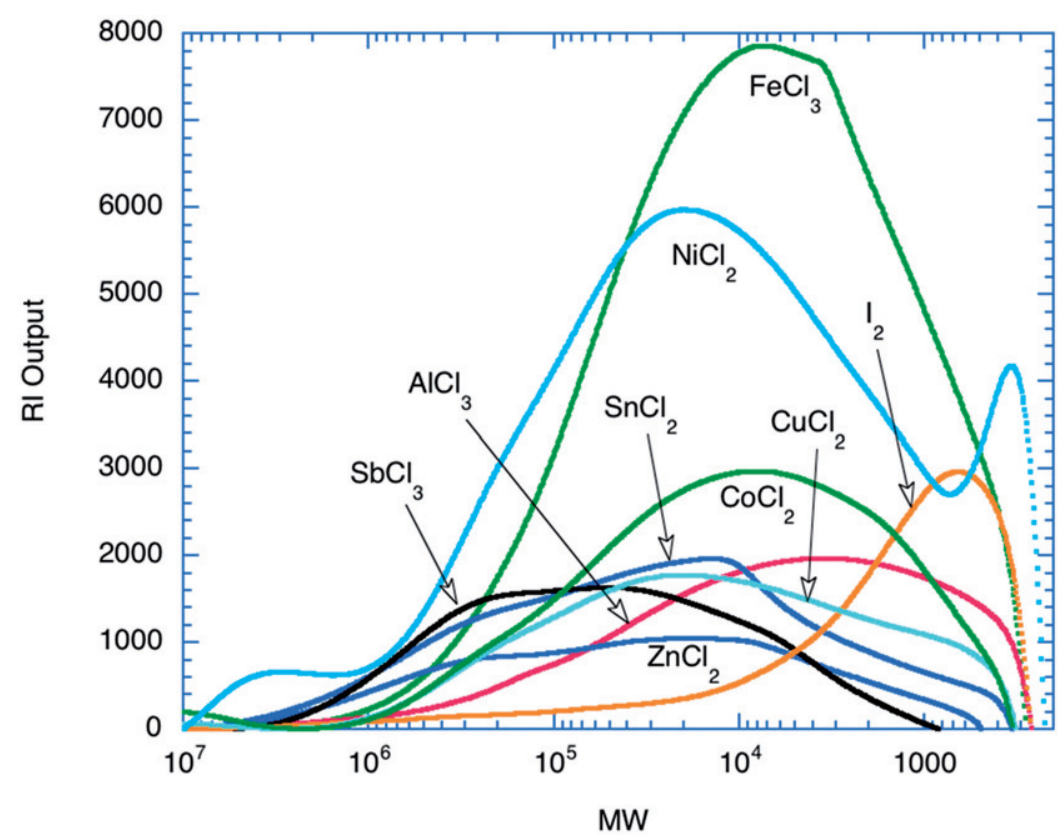

Figure 4. Size exclusion chromatography curves for nine samples of acetylated starch samples made through metal chloride and iodine catalysis. The reaction conditions entailed $0.5 \mathrm{~g}$ starch, $1 \mathrm{~mL}$ acetic anhydride, $0.05 \mathrm{~g}$ catalyst, $80^{\circ} \mathrm{C}$ reaction temperature, and $6 \mathrm{~h}$ reaction time.

The trend shown in our work appeared to be different from the Lewis acid classification published by Kobayashi et al ${ }^{[62]}$. However, it was somewhat similar to Olah's categorization of Lewis acids based on Friedel-Crafts reaction ${ }^{[61]}$. At $80^{\circ} \mathrm{C}$, the trend also approximately agreed with those published by Saito, et $\mathrm{al}^{[68]}$ for the metal chloride-catalyzed cationic polymerization of p-methylstyrene. As the metal part of the Lewis acid is often depicted as complexing with the substrate ${ }^{[69-70]}$, the following mechanism seems reasonable. Thus, $\mathrm{H}^{+}$(or $\mathrm{H}_{3} \mathrm{O}^{+}$) is formed as the byproduct of the reaction. The hydronium ions can then cause molecular weight degradation, as we indeed observed.<smiles></smiles>

where $\mathrm{R}=$ starch moiety, and $\mathrm{M}=$ metal cation. To confirm this mechanism, we obtained the $\mathrm{pH}$ values of eight aqueous metal halide solutions at $1 \mathrm{M}$ concentration; no starch or acetic anhydride 


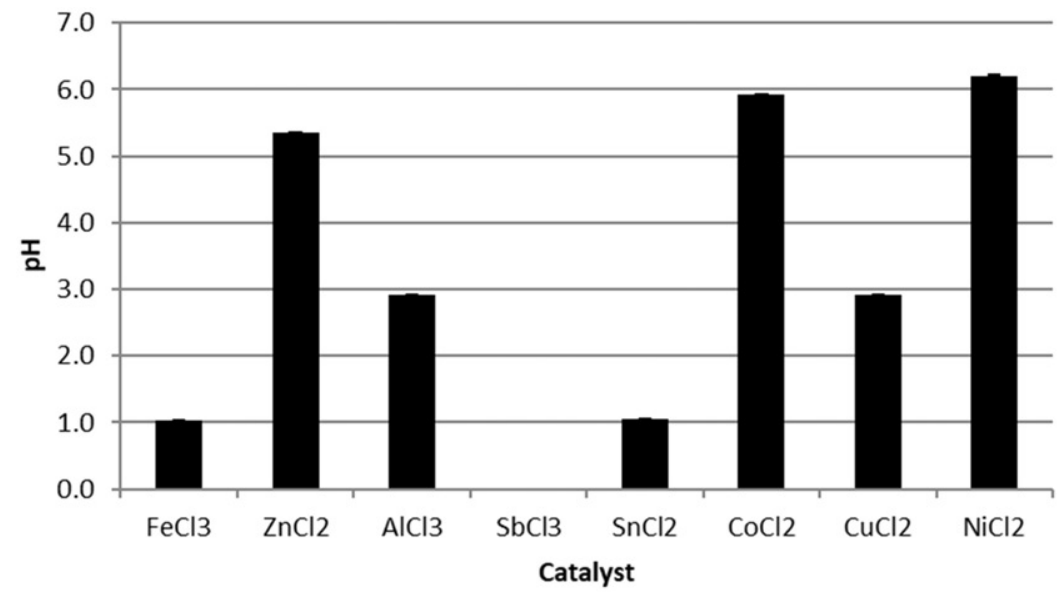

Figure 5. pH values for $1 \mathrm{M}$ concentration of metal chlorides in water.

was added. Data (Figure 5) indicated a range of $\mathrm{pH}$ values from 1.0 to 6.2. (No data were available for $\mathrm{SbCl}_{3}$ as it was not fully soluble at $1 \mathrm{M}$ concentration.) The trend of decreasing acidity is shown as follows:

$$
\mathrm{FeCl}_{3}>\mathrm{SnCl}_{2}>\mathrm{CuCl}_{2}>\mathrm{AlCl}_{3}>\mathrm{ZnCl}_{2}>\mathrm{CoCl}_{2}>\mathrm{NiCl}_{2}
$$

This $\mathrm{pH}$ trend appears to match roughly the $60^{\circ} \mathrm{C}$ reactivity of the metal chlorides for starch acetylation in our data, with the possible exception of $\mathrm{CuCl}_{2}$.

Note that the DS values obtained from the catalysis of metal chlorides in the anhydrous and hydrated forms are similar. As starch is known to contain a few percent of water even after drying, the presence of water does not seem to interfere with acetylation reaction. Likewise, the presence of water of hydration in the metal halide does not make a significant difference to the reaction.

\section{Conclusion}

Esterification of polysaccharide is commercially important, and additional information on the esterification processes should be desirable, especially if we can minimize the chemical hazards by not using strong mineral acids. In this work, we have shown that metal halides in general can be employed as catalysts for starch acetylation. Interestingly, a range of reactivities have been obtained, depending on the metal chloride chosen and the reaction conditions. Thus, it is possible to customize the reaction conditions as needed for a particular situation. For example, if a lower reaction temperature is desirable, then iodine or $\mathrm{FeCl}_{3}$ can be chosen as the catalyst at $60^{\circ} \mathrm{C}$. If a sample with a lower DS is needed, perhaps, $\mathrm{NiCl}_{2}$ and $\mathrm{CoCl}_{2}$ can be selected as they tend to be less reactive. If reduced molecular weight degradation is desirable, then $\mathrm{SnCl}_{2}$ and $\mathrm{ZnCl}_{2}$ are preferred. If the catalyst cost is an issue, the hydrated form of a metal chloride can be used instead of the more expensive anhydrous form. Although the emphasis of this work is starch acetylation, the same metal chlorides can be used for the esterification of other polysaccharides. This work is ongoing in our laboratories.

\section{Funding}

Thanks are due to Karl Vermillion for NMR data, and Jason Adkins for the SEC and thermal analysis data. Atanu Biswas and Roselayne Ferro Furtado thank Brazilian National Council for Scientific and Technological Development (CNPq, process no. 405506/2013-9) for support of this work through the Science without Borders program. Mention of trade names or commercial products in this publication is solely for the purpose of providing 
specific information and does not imply recommendation or endorsement by the U.S. Department of Agriculture. USDA is an equal opportunity provider and employer.

\section{ORCID}

Atanu Biswas (D) http://orcid.org/0000-0002-8112-1968

H. N. Cheng (iD http://orcid.org/0000-0001-8647-057X

\section{References}

[1] 2016. Chemical economics handbook. Cellulose Acetate Fibers https://www.ihs.com/products/cellulose-acetate-and-triacetate-chemical-economics-handbook.html

[2] Edgar, K. J., C. M. Buchanan, J. S. Debenham, P. A. Rundquist, B. D. Seiler, M. C. Shelton, and D. Tindall. 2001. Advances in cellulose ester performance and application. Prog. Polym. Sci. 26:1605-1688.

[3] Golachowski, A., T. Zięba, M. Kapelko-Żeberska, W. Drożdż, A. Gryszkin, and M. Grzechac. 2015. Current research addressing starch acetylation. Food Chem. 176:350-356.

[4] Ackar, D., J. Babic, A. Jozinović, B. Miličević, S. Jokic, R. Miličević, M. Rajič, and D. Šubarić. 2015. Starch modification by organic acids and their derivatives: a review. Molecules. 20:19554-19570.

[5] Abbas, K. A., S. K. Khalil, and A. Hussin. 2010. Modified starches and their usages in selected food products: a review study. Jas. 2:90-100.

[6] Ashogbon, A. O., and E. T. Akintayo. 2014. Recent trend in the physical and chemical modification of starches from different botanical sources: a review. Starch. 66:41-57.

[7] Cumpstey, I. 2013. Chemical modification of polysaccharides. ISRN Org. Chem. 2013:1. http://dx.doi.org/10. $1155 / 2013 / 417672$.

[8] Cheng, H. N., and Q.-M. Gu. 2012. Enzyme-catalyzed modifications of polysaccharides and poly(ethylene glycol). Polymers. 4:1311-1330.

[9] Fox, S. C., B. Li, D. Xu, and K. J. Edgar. 2011. Regioselective esterification and etherification of cellulose: a review. Biomacromolecules. 12:1956-1972.

[10] Heinze, T., T. Liebert, and A. Koschella. 2006. Esterification of Polysaccharides. Berlin, Germany: Springer.

[11] Li, X., W. Gao, Q. Jiang, L. Huang, and C. Liu. 2011. Study on the morphology, crystalline structure, and thermal properties of fritillaria ussuriensis maxim. Starch acetates with different degrees of substitution. Starch/Stärke. 63:24-31.

[12] Lu, K. C., S. Y. Hsieh, L. N. Patkar, C. T. Chen, and C. C. Lin. 2004. Simple and efficient per-O-acetylation of carbohydrates by lithium perchlorate catalyst. Tetrahedron. 60:8967-8973.

[13] Doyle, S., R. A. Pethrick, R. K. Harris, J. M. Lane, K. J. Packer, and F. Heatley. 1986. C nuclear magnetic resonance studies of cellulose acetate in the solution and solid states. Polymer. 27:19-24.

[14] Iwata, T., A. Fukushima, K. Okamura, and J. Azuma. 1997. DSC study on regioselectively substituted cellulose heteroesters. J. Appl. Polym. Sci. 65:1511-1515.

[15] Malm, C. J., L. J. Tanghe, H. M. Herzog, and M. H. Stewart. 1958. Reactivities of lower aliphatic anhydrides toward hydroxyl groups of cellulose. Ind. Eng. Chem. 50:1061-1066.

[16] Lee, J. C., C. A. Tai, and S. C. Hung. 2002. Sc(OTf $)_{3}$-catalyzed acetolysis of 1, 6-anhydro- $\beta$-hexopyranoses and solvent-free per-acetylation of hexoses. Tetrahedron Lett. 43:851-865.

[17] Shogren, R. 2008. Scandium triflate catalyzed acetylation of starch at low-to-moderate temperatures. Carbohydr. Polym. 72:439-443.

[18] Tai, A. A., S. S. Kulkarni, and S. C. Hung. 2003. Facile cu(OTf $)_{2}$-catalyzed preparation of per-O-acetylated hexopyranoses with stoichiometric acetic anhydride and sequential one-pot anomeric substitution to thioglycosides under solvent-free conditions. J. Org. Chem. 68:8719-8722.

[19] Das, S. K., K. A. Reddy, V. L. N. R. Krovvidi, and K. Mukkanti. 2005. $\mathrm{InCl}_{3}$ as a powerful catalyst for the acetylation of carbohydrate alcohols under microwave irradiation. Carbohydr. Res. 340:1387-1392.

[20] Ahmad, S., and J. Iqbal. 1987. A new acylation catalyst. J. Chem. Soc. Chem. Commun. 1987:114-115.

[21] Dasgupta, F., P. P. Singh, and H. C. Srivastava. 1980. Acetylation of carbohydrates using ferric chloride in acetic anhydride. Carbohydr. Res. 80:346-349.

[22] Montero, J. L., J. Y. Winum, A. Leydet, M. Kamal, A. A. Pavia, and J. P. Roque. 1997. A convenient synthesis of peracetylated glycosyl halides using bismuth (III) halides as catalysts. Carbohydr. Res. 297: 175-180.

[23] Kartha, K. P. R., and R. A. Field. 1997. Iodine: a versatile reagent in carbohydrate chemistry IV. PerO-acetylation, regioselective acylation and acetolysis. Tetrahedron. 53:11753-11766. 
[24] Biswas, A., G. S. Selling, R. L. Shogren, J. L. Willett, C. M. Buchanan, and H. N. Cheng. 2009. Iodine-catalyzed esterification of polysaccharides. Chem. Oggi (Chem. Today). 27:33-35.

[25] Cheng, H. N., M. K. Dowd, G. W. Selling, and A. Biswas. 2010. Synthesis of cellulose acetate from cotton byproducts. Carbohydr. Polym. 80:449-453.

[26] Liu, C. F., A. P. Zhang, W. Y. Li, F. X. Yue, and R. C. Sun. 2010. Succinoylation of cellulose catalyzed with iodine in ionic liquid. Ind. Crops Prod. 31:363-369.

[27] Eranna, P. B., K. K. Pandey, and G. B. Nagarajappa. 2016. A note on the effect of microwave heating on iodine-catalyzed acetylation of wood. J. Wood Chem. Technol. 36:205-210.

[28] Jarowenko, W. 1986. Acetylated starch and miscellaneous organic esters. In Modified Starches: Properties and Uses ed.O.B. Wurzburg pp. 55-77 Boca Raton, FL: CRC Press.

[29] Rutenberg, M. W., and D. Solarek. 1984. Starch derivatives: Production and uses. In Starch: Chemistry and Technology eds. R.L. Whistler, J.N. Bemiller, E.F. Paschall pp. 312-388. Orlando, FL: Academic Press.

[30] Sun, S.,. G. Zhang, and C. Ma. 2016. Preparation, physicochemical characterization and application of acetylated lotus rhizome starches. Carbohydr. Polym. 135:10-17.

[31] Colussi, R., S. L. M. El Halal, V. Z. Pinto, J. Bartz, L. C. Gutkoski, E. R. Zavareze, and A. R. G. Dias. 2015. Acetylation of rice starch in an aqueous medium for use in food. LWT-Food Sci. Technol. 62:1076-1082.

[32] Osundahunsi, O. F., K. T. Seidu, and R. Mueller. 2014. Effect of presence of sulphurdioxide on acetylation and sorption isotherm of acetylated starches from cultivars of cassava. Food Chem. 151:168-174.

[33] Zieba, T., M. Kapelko, and A. Szumny. 2013. Effect of preparation method on the properties of potato starch acetates with an equal degree of substitution. Carbohydr. Polym. 94:193-198.

[34] Mbougueng, P. D., D. Tenin, J. Scher, and C. Tchiégang. 2012. Influence of acetylation on physicochemical, functional and thermal properties of potato and cassava starches. J. Food Eng. 108:320-326.

[35] Bello-Pérez, L. A., E. Agama-Acevedo, P. B. Zamudio-Flores, G. Mendez-Montealvo, and S. L. RodriguezAmbriz. 2010. Effect of low and high acetylation degree in the morphological, physicochemical and structural characteristics of barley starch. LWT - Food. Sci. Technol. 43:1434-1440.

[36] Scriven, E. F. V. 1983. 4-Dialkylaminopyridines: super acylation and alkylation catalysts. Chem. Soc. Rev. 12:129-161.

[37] Tiwari, P., R. Kumar, P. R. Maulik, and A. K. Misra. 2005. Efficient acetylation of carbohydrates promoted by imidazole. Eur. J. Org. Chem. 2005:4265-4270.

[38] Schmidt, J. C. 1985. Process for producing esters of carbohydrate materials. U.S. Patent 4501888.

[39] Bushra, M., X. Xu, and S. Pan. 2013. Microwave assisted acetylation of mung bean starch and the catalytic activity of potassium carbonate in free-solvent reaction. Starch/Stärke. 65:236-243.

[40] Cao, Y., H. Li, and J. Zhang. 2011. Homogeneous synthesis and characterization of cellulose acetate butyrate $(\mathrm{CAB})$ in 1-allyl-3-methylimidazolium chloride (AmimCl) ionic liquid. Ind. Eng. Chem. Res. 50:7808-7814.

[41] Murugesan, S., N. Karst, T. Islam, J. M. Wiencek, and R. J. Linhardt. 2003. Dialkyl imidazolium benzoatesroom temperature ionic liquids useful in the peracetylation and perbenzoylation of simple and sulfated saccharides. Synlett 2003:1283-1286.

[42] Forsyth, S. A., D. R. MacFarlane, R. J. Thomson, and M. von Itzstein. 2002. Rapid, clean, and mild O-acetylation of alcohols and carbohydrates in an ionic liquid. Chem. Commun. 2002:714-715.

[43] Bhaskar, P. M., and D. Loganathan. 1998. Per-O-acetylation of sugars catalysed by montmorillonite K-10. Tetrahed. Lett. 39:2215-2218.

[44] Bhaskar, P. M., and D. Loganathan. 2010. H-Beta Zeolite as an efficient catalyst for per-O-acetylation of Mono-and disaccharides. Synlett 30:131.

[45] Kumareswaran, R., K. Pachamuthu, and Y. D. Vankar. 2000. Nafion-H catalyzed acetylation of alcohols. Synlett 2000:1652-1654.

[46] Tiwari, P., and A. K. Misra. 2006. Acylation of carbohydrates over $\mathrm{Al}_{2} \mathrm{O}_{3}$ : preparation of partially and fully acylated carbohydrate derivatives and acetylated glycosyl chlorides. Carbohydr. Res. 341:339-350.

[47] Misra, A. K., P. Tiwari, and S. K. Madhusudan. 2005. HClO4-SiO2 catalyzed per-O-acetylation of carbohydrates. Carbohydr. Res. 340:325-329.

[48] Abbott, A. P., T. J. Bell, S. Handa, and B. Stoddart. 2005. O-Acetylation Of cellulose and monosaccharides using a zinc based ionic liquid. Green Chem. 7:705-707.

[49] Yang, Y., L. Song, C. Peng, E. Liu, and H. Xie. 2015. Activating cellulose via its reversible reaction with $\mathrm{CO}_{2}$ in the presence of 1,8-diazabicyclo[5.4.0]undec-7-ene for the efficient synthesis of cellulose acetate. Green Chem. 17:2758-2763.

[50] Falk, H., M. Stanek, and R. Wutka. 1997. Structural aspects of partially acetylated degraded amylopectin a ${ }^{13} \mathrm{C}$ NMR study. Starch/Stärke. 49:488-491.

[51] Kono, H., H. Hashimoto, and Y. Shimizu. 2015. NMR characterization of cellulose acetate: chemical shift assignments, substituent effects, and chemical shift additivity. Carbohydr. Polym. 118:91-100. 
[52] Cheng, H. N., and L. J. Kasehagen. 1994. Integrated approach for ${ }^{13} \mathrm{C}$ NMR shift prediction, spectral simulation and library search. Anal. Chem. Acta. 285:223-235.

[53] Cheng, H. N., and T. G. Neiss. 2012. NMR spectroscopy of food polysaccharides in solution. Polym. Rev. 52:81-114.

[54] Warren, F. J., M. J. Gidley, and B. M. Flanagan. 2016. Infrared spectroscopy as a tool to characterise starch ordered structure-a joint FTIR-ATR, NMR, XRD and DSC study. Carbohydr. Polym. 139:35-42.

[55] Siesler, H. W. 2011. Vibrational spectroscopy of polymers. Int. J. Polym. Anal. Charac 16:519-541.

[56] Chi, H., K. Xu, X. Wu, Q. Chen, D. Xue, C. Song, W. Zhang, and P. Wang. 2008. Effect of acetylation on the properties of corn starch. Food Chem. 106:923-928.

[57] Mina, J., A. Valadez-Gonsalez, P. Herrera-Franco, F. Zuluaga, and S. Delwasta. 2011. Physicochemical characterization of natural and acetylated thermoplastic cassava starch. Dyna 78:166-173. http://www.scielo. org.co/pdf/dyna/v78n166/a20v78n166.pdf.

[58] Elomaa, M., T. Asplund, P. Soininen, R. Laatikainen, S. Peltonen, S. Hyvarinen, and A. Urtti. 2004. Determination of the degree of substitution of acetylated starch by hydrolysis, ${ }^{1} \mathrm{H}$ NMR and TGA/IR. Carbohydr. Polym. 57:261-267.

[59] Gutmann, V. 1976. Solvent effects on the reactivities of organometallic compounds. Coordination. Chem. Rev. 18:225-255.

[60] Beckett, M. A., G. C. Strickland, J. R. Holland, and K. S. Varma. 1996. A convenient NMR method for the measurement of lewis acidity at boron centers: correlation of reaction rates of lewis acid initiated epoxide polymerizations with lewis acidity. Polym. Comm. 37:4629-4631.

[61] Olah, G. A., S. Kobayashi, and M. Tashiro. 1972. Aromatic substitutions. XXX. Friedel-Crafts Benzylation of benzene and toluene with benzyl and substituted benzyl halides. J. Am. Chem. Soc. 94:7448-7461.

[62] Kobayashi, S., T. Busujima, and S. Nagayama. 2000. A novel classification of lewis acids on the basis of activity and selectivity. Chemistry 6:3491-3494.

[63] Satchell, D. P. N., and R. S. Satchell. 1969. Quantitative aspects of the lewis acidity of covalent metal halides and their organo derivatives. Chem. Rev. 69:251-278.

[64] Laszlo, P., and M. Teston. 1990. Determination of the acidity of lewis acids. J. Am. Chem. Soc. 112:8750-8754.

[65] Christe, K. O., D. A. Dixon, D. McLemore, W. W. Wilson, J. A. Sheehy, and J. A. Boatz. 2000. On a quantitative scale for lewis acidity and recent progress in polynitrogen chemistry. J. Fluorine Chem. 101:151-153.

[66] Britovsek, G. J. P., J. Ugolotti, and A. J. P. White. 2005. From $B\left(\mathrm{C}_{6} \mathrm{~F}_{5}\right)_{3}$ to $\mathrm{B}\left(\mathrm{OC}_{6} \mathrm{~F}_{5}\right)_{3}$ : Synthesis of $\left(\mathrm{C}_{6} \mathrm{~F}_{5}\right)_{2} \mathrm{BOC}_{6} \mathrm{~F}_{5}$ and $\mathrm{C}_{6} \mathrm{~F}_{5} \mathrm{~B}\left(\mathrm{OC}_{6} \mathrm{~F}_{5}\right)_{2}$ and their relative lewis acidity. Organometallics 24:1685-1691.

[67] Hilt, G., F. Pünner, J. Mobus, V. Naseri, and M. A. Bohn. 2011. A lewis acidity scale in relation to rate constants of lewis acid catalyzed organic reactions. Eur. J. Org. Chem. 2011:5962-5966.

[68] Saito, R., A. Kanazawa, S. Kanaoka, and S. Aoshima. 2016. Cationic polymerization of p-methylstyrene using various metal chlorides: design rationale of initiating systems for controlled polymerization of styrene. Polym. J. 48:933-940.

[69] Odian, G. 2004. Principles of Polymerization, 4th ed. Hoboken, NJ: Wiley; pp. 374-378.

[70] Borah, R., N. Deka, and J. C. J. Sarma. 1997. Iodine as an acetyl transfer catalyst. J. Chem. Res. 1997:110-111. 